\title{
PEMBINAAN KARAKTER MELALUI PELATIHAN BERBICARA DI DEPAN UMUM PADA ANGGOTA PRAMUKA SMA NEGERI 5 MATARAM
}

\author{
${ }^{1}$ Baiq Desi Milandari, ${ }^{2}$ Ahyati Kurniamala N., ${ }^{3}$ Roby Mandalika Waluyan, \\ ${ }^{4}$ Akhmad H. Mus, ${ }^{5} \mathrm{Nina}$ \\ 1,2,3,4,5Pendidikan Bahasa Indonesia, Universitas Muhamadiyah Mataram \\ desibaiq_lt@yahoo.co.id
}

\begin{abstract}
ABSTRAK
Abstrak: Kegiatan pengabdian pada masyarakat ini merupakan kegiatan yang dilakukan sebagai wujud pembinaan kepada masyarakat. Pengabdian ini dilaksanakan pada anggota pramuka di SMA Negeri 5 Mataram. Kegiatan pengabdian ini dilaksanakan dalam rangka melakukan pembinaan materi berbicara di depan umum pada anggota pramuka. Pelatihan berbicara di depan umum ini dimaksudkan agar para anggota pramuka di gugus depan 06.101-06.102 Ambalan Udayana-Ratu Sima, mampu berbicara di depan umum dengan bahasa yang baik dan benar serta menjunjung kesantunan berbahasa, hal ini dimaksudkan untuk membentuk karakter anggota pramuka sejak dini, sehingga di kemudian hari mereka menjadi unggul di masyarakat dalam hal positif. Kegiatan tersebut dilaksanakan sebanyak 4 kali pertemuan dengan rincian: (1) Pertemuan I: Penyampaian materi tentang keterampilan berbicara di depan umum; (2) Pertemuan II: Pelatihan berpidato dan memandu acara; (3) Pertemuan III: Pelatihan berdiskusi dan memimpin rapat; (4) Pertemuan IV: Evaluasi kegiatan.

Kata Kunci : Pembinaan, Karakter, Berbicara

Abstract: The community service activities is a activities performed as a form of coaching to the community. This dedication was held on members of Pramuka in Senior High School 5 Mataram. This devotion activities implemented in order doing coaching matter of public speaking on the members of Pramuka. This public speaking training is intended in order for the members of the Pramuka in gugus depan 06.101-06.102 Ambalan Udayana-Ratu Sima, being able to speak in public with proper grammar and correct as well as the respect politeness language, it is intended to forming the character of the members Pramuka since the early. So that later in life they became superior in the community in terms of positive. The activities carried out by as much as 4 times, with details: (1) the first meeting I: delivery of material about public speaking skills; (2) the second meeting II: addressing the hourlong training; (3) the third meeting III : discuss and lead training; (4) the fourth meeting IV : evaluation activities.
\end{abstract}

Keywords: Development, Character, Speaking.

Riwayat Artikel: Diterima: 2 Desember 2017, Disetujui: 24 Januari 2018 


\section{A. PENDAHULUAN}

Pada era globalisasi seperti saat ini, segala bentuk teknologi berkembang begitu pesat. Perkembangan teknologi tersebut berdampak pada karakter anak bangsa. Jika berbicara tentang dampak, maka akan ada dampak positif dan negatif yang akan ditimbulkan. Dampak positif dari perkembangan teknologi bagi anak yaitu anak tidak tertinggal dengan kemajuan teknologi digital seperti saat ini, dapat dimanfaatkan sebagai media belajar yang menarik, kemudahan memperoleh ilmu pengetahua.Di sisi lain, dampak negatifnya adalah apabila anak terlalu banyak menggunakan teknologi, misal gadget maka anak akan kurang aktif bergerak dan kurang bersosialisasi dengan orang lain dan lingkungan (Fatimah, 2015).

Kebiasaan anak-anak pada saat ini terpaku pada dunianya sendiri, sehingga kurangnya jiwa empati atau peduli dengan lingkungan. Hal ini menyebabkan kurangnya komunikatif pada anak. Mereka bahkan terkadang tidak memahami bagaimana cara berkomunikasi yang baik dan benar dengan orang lain.

Berbicara dengan orang lain pada forum-forum tertentu, tentunya harus memiliki tata cara yang baik sehingga dapat menimbulkan kesan yang positif. Kegiatan berbicara di depan umum, di antaranyya adalah pada saat berdiskusi, berpidato, melaporkan hasil kegiatan, memandu acara, dan sebagainya. Pada kegiatan pengabdian ini, tim akan lebih fokus memberikan pelatihan bagaimana tata cara berbicara di depan umum secara umum. Artinya pelatihan ini tidak terfokus pada satu jenis kegiatan saja, seperti berdiskusi maupun yang lainnya.

Organisasi pramuka merupakan salah satu organisasi kepemudaan yang fokus di bidang pendidikan anak bangsa. Kegiatan-kegiatan pramuka selalu menekankan pada pembentukan karakter. Karakter diartikan sebagai tabiat, sifat-sifat kejiwaan, akhlak atau budi pekerti yang membedakan seseorang dengan yang lain, dan watak (Zuchdi, 2012: 16). Pembentukan karakter yang dimaksud adalah pembentukan watak anak kearah yang positif. Melalui pembentukan karakter yang positif, diharapkan anak-anak pramuka dapat menjadi penerus bagi bangsa Indonesia.

Kegiatan pramuka tidak hanya terbatas pada materi kepramukaan saja, melainkan diberikan pelatihan-pelatihan berupa soft skill yang nantinya dapat mereka pergunakan di dalam bermasyarakat. Kegiatan pramuka dalam pembentukan karakter dapat dilakukan melalui berbagai cara. Salah satunya adalah melalui kegiatan pelatihan berbicara di depan umum. Pelatihan ini diharapkan dapat membentuk karakter anggota pramuka agar menjadi pribadi yang pemberani, kritis, bertanggung jawab namun tetap memiliki etika kesopanan dalam bertutur kataserta berkomunikasi dengan orang lain.

Adapun mitra kegiatan pengabdian ini adalah anggota pramuka SMA Negeri 5 Mataram, gugus depan 06.101-06.102 Ambalan Udayana-Ratu Sima yang terletak di Jalan Udayan No. 2A Mataram, NTB. Kegiatan pengabdian tersebut diikuti oleh 25 orang peserta Pramuka aktif yang merupakan siswa-siswi kelas X dan XII.

Berdasarkan pemaparan analisis situasi di atas, permasalahan yang ditemukan di lapangan di antaranya: 1) banyaknya anggota pramuka yang belum mampu mengutarakan pendapat pada kegiatan-kegiatan resmi, seperti rapat atau pada saat menyampaikan materi atau informasi, 2) terdapat beberapa anggota pramuka yang belum mengetahui etika berbahasa yang baik di depan umum, 3) ketidak terampilan 
anggota pramuka berbicara di depan umum berpengaruh pada keberanian dan sikap tidak percaya diri.

Oleh karena itu, melihat berbagai macam permasalahan tersebut, tim pengabdian memutuskan untuk melakukan program pembinaan serta pelatihan bagi para anggota pramuka di SMA 5 Mataram tentang bagaimana cara berbicara di depan umum, termasuk tata cara menyampaiakan pendapat di forum-forum resmi dengan menggunakan bahasa Indonesia yang baik dan benar.

\section{B. METODE PELAKSANAAN KEGIATAN}

Kegiatan pengabdian dengan judul "Pembinaan Karakter Melalui Pelatihhan Berbicara di Depan Umum pada Anggota Pramuka SMA Negeri 5 Mataram" berlangsung selama 2 bulan yaitu dari bulan Oktober-November 2017. Pelaksanaan kegiatan pengabdian ini dilakukan dengan menggunakan metode latihan, penugasan, presentasi, dan diskusi. Kegiatan pelatihan tersebut tidak hanya dilakukan di ruang kelas saja, namun dilakukan di luar kelas seperti lapangan SMA Negeri 5 Mataram atau pada saat kegiatan persami (perkemahan Sabtu-Minggu) di alam terbuka. Hal ini dilakukan karena didasari pada prinsip pembelajaran kepramukaan yang mengutamakan suasana menyenangkan dan rasa gembira pada anggota yang mengikuti kegiatan pelatihan tersebut.

\section{Tahap Persiapan}

Tahap persiapan merupakan tahap awal yang dilakukan oleh tim sebelum melakukan pengabdian di lapangan. Tahapan ini bertujuan untuk mempersiapkan segala sesuatu yang menunjang proses pengabdian nanti. Kegiatan yang dilakukan pada tahap ini adalah sebagai berikut.

a. Melakukan sosialisasi dan komunikasi dengan pihak sekolah, seperti kepala sekolah dan pembina pramuka SMA Negeri 5 Mataram.

b. Melakukan observasi tentang kondisi awal di lapangan serta wawancara dengan Pembina pramuka terkait persoalan di lapangan.

c. Menyusun jadwal pelaksanaan kegiatan.

d. Menyiapkan materi pelatihan.

\section{Tahap Pelaksanaan}

Pada tahapan ini tim mulai melakukan kegiatan pengabdian dengan melakukan pelatihan berbicara di depan umum pada anggota pramuka SMA Negeri 5 Mataram. Kegiatan tersebut dilaksanakan sebanyak 4 kali pertemuan. Rincian kegiatan diuraikan di bawah ini.

a. Pertemuan I: Penyampaian materi tentang keterampilan berbicara di depan umum.

b. Pertemuan II: Pelatihan berpidato dan memandu acara.

c. Pertemuan III: Pelatihan berdiskusi dan memimpin rapat.

d. Pertemuan IV: Evaluasi kegiatan.

\section{HASIL DAN PEMBAHASAN}

\section{Kegiatan Awal}

Kegiatan pengabdian pada masyarakat ini dilakukan di SMA Negeri 5 Mataram dengan anggota pramuka sebagai mitra kegiatan. Pengabdian tersebut berlangsung selama 2 bulan, dimulai dari bulan Oktober-November 2017. Pelatihan ini dilaksanakan pada tiap hari Jumat, yang dimulai pukul 16.00-17.30 
Wita. Jumlah peserta pelatihan sebanyak 25 orang yang terdiri dari kelas X dan XII (daftar hadir terlampir). Sebelum memulai pelatihan, tim terlebih dahulu melakukan sosialisasi dan komunikasi dengan pihak sekolah, seperti Kepala Sekolah dan Pembina Pramuka SMA Negeri 5 Mataram guna kelancaran kegiatan tersebut. Sosialisasi ini dilaksanakan pada hari Selasa, 3 Oktober 2017. Pihak sekolah mendukung penuh rencana kegiatan pelatihan yang akan dilaksanakan. Setelah memperoleh izin dari pihak sekolah, tim kemudian melakukan observasi tentang kondisi awal di lapangan serta wawancara dengan Pembina Pramuka terkait persoalan di lapangan. Dari hasil observasi dan wawancara dengan Pembina Pramuka, ditemukan persoalan bahwa banyak di antara anggota Pramuka yang mengalami kesulitan untuk berbicara pada forumforum diskusi. Dengan kata lain, anggota pramuka di SMA Negeri 5 Mataram masih belum sepenuhnya mampu mengungkapkan pendapat dan pikiran dalam kegiatan-kegiatan diskusi.

Setelah melakukan sosialisasi dan observasi keadaan awal, tim kemudian membuat materi pelatihan tentang keterampilan berbicara di depan umum serta menyusun pelaksanaan kegiatan. Kegiatan pelatihan tersebut dilakukan selama 4 kali pertemuan. Setiap pertemuan dilaksanakan sekali dalam sepekan, yaitu pada hari Jumat. Penyusunan jadwal pelatihan disesuaikan dengan jadwal latihan Pramuka di SMA Negeri 5 Mataram. Hal ini bertujuan agar tidak mengganggu jadwal latihan ektrakurikuler lain yang juga diikuti oleh anggota pramuka.

\section{Pelatihan Berbicara di Depan Umum Bagi Anggota Pramuka SMA Negeri 5 Mataram}

SMA Negeri 5 Mataram merupakan salah satu SMA yang ada di Kota Mataram. SMA Negeri 5 Mataram terletak di Jalan Udayana, No. 2A Mataram, Nusa Tenggara Barat. Dalam proses belajar mengajar, sekolah tersebut menerapkan Kurikulum 2013 yang mewajibkan semua siswa kelas X mengikuti kegiatan kepramukaan. Ada dua system yang digunakan dalam melaksanakan kegiatan kepramukaan bagi kelas X, yaitu system sukarela dan system terjadwal. System sukarela adalah perekrutan anggota pramuka yang memang sejak awal terlibat aktif dalam organisasi kepramukaan serta memiliki komitmen untuk tetap aktif mengikuti latihan setiap pekan. Anggota pramuka aktif tersebut disebut sebagai pramuka inti. System terjadwal adalah pelaksanaan kegiatan pramuka untuk siswa kelas X secara menyeluruh pelaksanaan kegiatan tersebut dilakukan pada hari Sabtu jam pelajaran terakhir guna melaksanakan salah satu kewajiban sebagai upaya pelaksanaan K13.

Keberadaan ekstrakurikuler Pramuka di SMA Negeri 5 Mataram telah ada sejak dulu, namun bersifat pasif. Oleh karena itu, melalui penerapan K13 pihak sekolah meminta Pembina pramuka untuk kembali mengaktifkan ekstrakurikuler tersebut dengan melakukan penerimaan anggota baru. Selama 2 tahun terakhir ini, anggota aktif pramuka berjumlah \pm 30 orang yang terdiri dari siswa kelas $\mathrm{X}$ dan XI. Dengan melihat antusias dan semangat anggota, pada tanggal 15 September 2017 dibentuklah Ambalan yang diberi nama Ambalan Udayana untuk putra dan Ambalan Ratusima untuk putri.

Dalam kegiatan tersebut, peserta yang mengikuti pelatihan berjumlah 25 orang yang terdiri atas siswa kelas X dan XI (nama terlampir). Berdasarkan 
paparan sebelumnya, pelatihan ini dilaksanakan selama 4 kali pertemuan. Adapun rincian kegiatan tiap-tiap pertemuanakan dipaparak sebagai berikut.

a. Pertemuan I

Pertemuan I dilaksanakan pada Jumat, tanggal 27 oktober 2017. Pada pertemuan I, kegiatan dimulai pada pukul 15.00 Wita yang diawali dengan acara pembukaan dan dihadiri langsung oleh Pembina Pramuka SMA Negeri 5 Mataram. Setelah itu, pada pukul 16.00 Wita dilakukan penyampaian materi tentang keterampilan berbicara di depan umum, seperti keterampilan berpidato, memandu acara, berdiskusi dan memimpin diskusi. Penyampaian materi ini penting karena memberikan pengetahuan awal tentang bagaimana dan hal-hal apa saja yang harus dipahami sebelum mengaplikasikannya secara langsung pada forum-forum tertentu.

\section{b. Pertemuan II}

Pada pertemuan II, peserta sudah mulai diminta untuk mengaplikasikan teori tentang bagaimana berpidato yang baik dan benar serta bagaiamana tatta cara memandu acar baik formal maupun nonformal. Kegiatan ini bertujuan untuk memberikan soft skill pada peserta yang nanti dikemudian hari dapat digunakan sebagi bekal di masyarakat. Pertemuan ini dilaksanakan pada Jumat, 3 November 2017 pada pukul 16.00-17.30 Wita di ruang laboratorium Biologi SMA Negeri 5 Mataram.

Pada pelaksanaannya, tim pelaksana pengabdian meminta peserta untuk menyampaikan contoh sambutan ketua panitia dalam sebuah acara. Selain sambutan ketua panitia, peserta pelatihan juga diminta untuk menyusun sebuah rangkaian acara untuk kemudian dipraktikkan tentang tata cara membawa acara yang baik dan benar. sama halnya dengan pelatihan memberi sambutan, tim pelaksana penggabdian juga menunjuk peserta secara acak untuk mempraktikkan bagaimana memandu acara. Metode ini dilakukan untuk membina karakter peserta agar selalu siap, berani, dan mandiri apabila suatu saat nanti diberi tanggung jawab untuk memandu sebuah acara. Di akhir pertemuan, tim pengabdian dengan peserta melakukan evaluasi dan refleksi terkait dengan kegiatan pelatihan pada hari tersebut.

\section{c. Pertemuan III}

Pertemuan III dilaksanakan pada tanggal 10 November 2017 di ruang kelas Kimia SMA Negeri 5 Mataram. Waktu pelaksanaan kegiatan ini sama dengan pertemuan-pertemuan sebelumnya yaitu dimulai pada pukul 16.00-17.30 Wita. Materi pelatihan pertemuan III yaitu tentang pelatihan berdiskusi dan memimpin rapat/diskusi. Tim membagi peserta pelatihan menjadi beberapa kelompok yang tiap-tiap kelompok diberi kesempatan untuk mendiskusikan tentang dampak pramuka bagi pendidikan karakter anak bangsa. Metode diskusi kelompok ini bertujuan untuk membangun karakter bekerja sama antar anggota kelompok dalam memecahkan permasalahan yang diberikan. Setelah terjadi diskusi kelompok, langkah selanjutnya adalah dengan melakukan diskusi secara klasikal dan menyeluruh. Salah satu peserta diminta untuk menjadi pemimpin diskusi/moderator dan satu peserta lagi diminta menjadi notulis. Pembinaan karakter yang terbentuk dari kegiatan 
ini adalah untuk membina anggota pramuka yang memiliki jiwa kepemimpinan, berani, santun, dan kritis. Di akhir pertemuan, tim bersama dengan peserta melakukan refleksi dari hasil kegiatan tersebut.

\section{d. Pertemuan IV}

Pelaksanaan pertemuan IV agak sedikit berbeda dengan pertemuan sebelumnya. Pertemuan IV yang sekaligus merupakan pertemuan terakhir terangkai dalam kegiatan PERSAMI (Perkemahan Sabtu-Minggu) yang dilaksanakan di bumi perkemahan Jakamandala Kwarda NTB. Kegiatan PERSAMI tersebut dilaksanakan pada tanggal 18-19 November 2017. Di selasela kegiatan, tim bersama dengan peserta melakukan evaluasi terkait dengan kegiatan pelatihan. Hasil akhir yang tampak adalah kecenderungan peserta untuk lebih berani mengungkapkan ide dan gagasannya. Terlihat pula pada peserta cara berdiskusi yang baik dan benar, cara menyanggah ppendapat teman, saar berdiskusi juga berjalan lebih tenang jika dibandingkan dengan suasana diskusi sebelum adanya pelatihan.

\section{PENUTUP}

\section{Simpulan}

Berdasarkan pembahasan di atas, dapat disimpukan bahwa kegiatan pengabdian tersebut sebagai berikut. 1) Pertemuan I dilaksanakan pada tanggal 27 November 2017 di ruang laboratorium Biologi SMA Negeri 5 Mataram dengan materi pelatihan yakni keterampilan berbicara, jenis-jenis keterampilan berbicara di depan umum, serta hal-hal yang harus diperhatikan saat berbicara di depan umum. 2) Pertemuan II dilaksanakan pada tanggal 3 November 2017 di ruang laboratorium Biologi SMA Negeri 5 Mataram pukul 16.00-17.30 Wita dengan materi pelatihan berpidato dan memandu acara. 3) Pertemuan III dilaksanakan pada tanggal 10 November 2017 di ruang kelas Kimia SMA Negeri 5 Mataram dimulai pada pukul 16.00-17.30 Wita. Materi pelatihan yaitu berdiskusi dan memimpin diskusi (moderator). 4) Pertemuan IV dilaksanakan pada tanggal 18-19 November yang dirangkaikan dengan kegiatan PERSAMI (Perkemahan Sabtu-Minggu) bertempat di bumi perkemahan Jakamandala Kwarda NTB. Pertemuan ini merupakan pertemuan akhir untuk mengevaluasi rangkaian kegiatan pelatihan.

\section{Saran}

Hasil pengabdian ini dapat memberikan dampak bagi perkembangan karakter remaja. Oleh karena itu, diharapkan adanya pelatihan serta pembinaan yang serupa yang dilakukan oleh tim pengabdian lainnya guna menumbuh kembangkan karakter positif dalam diri remaja serta mempersiapkan bekal bagi mereka berupa keterampilan-keterampilan yang dapat digunakan dalam keterlibatan mereka membangun masyarakat yang lebih baik. Terkait dengan pelatihan berbicara di depan umum, hendaknya guru juga terlibat dalam membangun kebiasaan siswa berbicara di depan uum dengan cara yang baik dan benar, serta menjunjung adab kesopanan berpendapat. Selanjutnya, kepada para anggota pramuka diharapkan untuk lebih banyak lagi belajar dan berlatih terutama berbicara di depan umum, sehingga mampu menjadi generasi muda panutan yang andal dalam segala bidang. 


\section{UCAPAN TERIMA KASIH}

Tim Penulis mengucapkan terima kasih kepada pihak-pihak yang telah terlibat baik secara langsung maupun tidak dalam kegiatan pengabdian ini. Pertama, terima kasih penulis ucapkan kepada pihak Lembaga Pengabdian Pada Masyarakat (LPPM) Universitas Muhammadiyah Mataram yang telah mendanai kegiatan pengabdian ini sehingga dapat terlaksana sebagaimana mestinya. Kedua, ucapan terima kasih kepada pihak SMA Negeri 5 Mataram, khususnya kepada Kepala Sekolah yang telah memberikan izin untuk melaksanakan pelatihan dan pembinaan pada siswa anggota Pramuka. Selain itu, kami juga menyampaiakan terima kasih kepada Pembina Pramuka SMA Negeri 5 Mataram yang telah membantu mengarahkan anggotanya untuk tetap mengikuti kegiatan ini sampai selesai. Terima kasih juga untuk adikadik anggota Pramuka Ambalan Udayana-Ratu Sima yang telah meluangkan waktunya untuk mengikuti kegiatan pelatihan ini dengan sangat baik.

\section{DAFTAR PUSTAKA}

DP2M Dikti. Buku Panduan Pelaksanaan Penelitian dan Pengabdian Kepada Masyarakat Edisi XI Tahun 2017. Jakarta, 2017.

Fatimah. "Dampak Positif dan Negatif Teknologi bagi Perkembangan Anak". Diaskses melalui https://nyupang99.wordpress.com pada tanggal 6 Desember 2017.

LPM Universitas Muhammadiyah Mataram. Rencana Strategi LPM Universitas Muhammadiyah Mataram. Mataram: Universitas Muhammadiyah Mataram, 2014

Sugihastuti. 2014. Bahasa Laporan Penelitian. Yogyakarta: Pustaka Pelajar Offset Zuchdi, Darmiyati dkk. Pendidikan Karakter: Konsep Dasar dan Implementasi di Perguruan Tinggi. Yogyakarta: UNY Press, 2012 